\title{
Deskripsi Kemampuan Membuat Soal Interaktif Mahasiswa Calon Guru di STKIP-PI Makassar
}

\author{
Khadijah, Wiwik Wiji Astuti, Andi Bida Purnamasari, Fandi Ahmad \\ Jurusan Pendidikan Biologi \\ STKIP Pembangunan Indonesia
}

\begin{abstract}
Abstrak
Tujuan kegiatan ini yaitu hendak mengupayakan pengembangan keterampilan dan kemampuan professional guru dalam mengembangkan soal interaktif sebagai upaya peningkatan kualitas pendidikan di era teknologi seperti sekarang ini. Materi pembelajaran yang disajikan tidak lengkap tanpa adanya soal-soal latihan, untuk memastikan bahwa soal yang diberikan dikerjakan langsung oleh siswa tanpa menyontek dan agar siswa dapat menilai dirinya sendiri maka sebaiknya soal diberikan dengan menggunakan teknologi yang interaktif. Belum adanya keterampilan pembuatan soal dengan teknologi yang interaktif bagi mahasiswa calon guru di kampus mitra menjadi pendorong pelaksanaan kegiatan pelatihan ini. Untuk itu, kegiatan ini akan memberikan pelatihan pembuatan soal interaktif, agar nantinya mahasiswa calon guru di kampus mitra mampu membuat sendiri soal yang bersifat interaktif. Metode penyajian materi dan praktikum pelatihan yaitu metode ceramah dan diskusi tanya jawab. Hasil yang dicapai berupa pengetahuan cara mengoptimalkan kegiatan pembelajaran dengan penggunaan teknologi yaitu dengan melibatkan tampilan yang menarik dari suatu aplikasi komputer, meningkatnya kemampuan dan keterampilan mahasiswa calon guru dalam membuat soal interaktif. Hal tersebut tampak dari hasil kerja mandiri peserta dalam menghasilkan soal interaktif yang menarik. Hasil kegiatan juga berupa antusiasme dan semangat peserta pelatihan yang tampak dari kehadiran peserta dan ketertarikan untuk lebih mendalami materi. Pemahaman dan keterampilan pembuatan soal interaktif juga cukup tinggi yang tampak dari penguasaan langkah pembuatan dan kreasi tampilan soal interaktif.
\end{abstract}

Kata Kunci: Soal Interaktif, teknologi pembelajaran

\section{PENDAHULUAN}

Materi pembelajaran yang disajikan tidak lengkap tanpa adanya soal-soal latihan. Untuk memastikan bahwa soal yang diberikan dikerjakan langsung oleh siswa tanpa menyontek dan agar siswa dapat menilai dirinya sendiri maka sebaiknya soal diberikan dengan menggunakan teknologi yang interaktif. Teknologi berupa komputer dapat digunakan untuk mengurangi kebiasaan menyontek bagi siswa dan dapat membantu siswa menilai kemampuannya sendiri, hal ini sesuai dengan sifat komputer yang digunakan per individu.

Pelatihan pembuatan soal interaktif ini menggunakan software Microsoft Power Point dengan program trigger. Pemilihan Microsoft Power Point karena merupakan software standar yang dimiliki oleh semua komputer sehingga tidak perlu lagi penginstalan khusus dan dapat terbaca di semua komputer. Microsoft Power Point juga merupakan aplikasi yang dapat dibuka di smartphone, sehingga siswa yang menggunakan smartphone dapat mengambil soal 
interaktifnya dan mengerjakan kembali lewat smartphone. Selain itu, masih banyak yang belum mengetahui bahwa Microsoft Power Point dapat dimanfaatkan bukan hanya dalam membuat slide persentasi tetapi juga dalam membuat soal interaktif, sehingga siswa menerima respon saat melaksanakan evaluasi dengan Microsoft Power Point.

Sekolah-sekolah negeri di Indonesia khususnya yang ada di Makassar sudah menyediakan sarana teknologi berupa komputer, LCD, speaker, Laboratorium Komputer dan laptop bagi guru-guru. Sudah selayaknya sebagai seorang calon guru memiliki kesiapan dalam menggunakan teknologi yang ada. Namun berdasarkan pengamatan di kampus STKIP Pembangunan Indonesia, mahasiswa calon guru masih kurang dalam penguasaan teknologi khususnya dalam pengembangan media pembelajaran dan soal interaktif. Karena itu penting adanya pelatihan teknologi bagi para calon guru masa depan seperti pelatihan pembuatan soal interaktif.

Sesuai dengan berbagai keputusan yang berkaitan dengan pengembangan keterampilan, maka sebagai wujud pengabdian pada masyarakat dalam upaya membantu pengembangan pengetahuan dan keterampilan guru dalam pembuatan soal interaktif, dan sebagai misi dari perguruan tinggi STKIP Pembangunan Indonesia dalam menyiapkan tenaga pengajar yang berkualitas maka kegiatan pelatihan dilakukan sebagai bagian dari kepedulian dalam mengembangkan misi pengembangan kemampuan professional guru. Pelaksanaan kegiatan ini menyangkut pemberian penjelasan tentang cara mengoptimalkan pembelajaran dengan teknologi komputer, fungsi-fungsi tampilan Microsoft Power Point untuk pembuatan soal interaktif, tata cara pembuatan soal interaktif yang kemudian dilanjutkan dengan pendampingan praktek langsung pembuatan soal interaktif.

\section{METODE}

Alat yang digunakan dalam pelatihan berupa alat IT seperti komputer dan perangkatnya/ laptop, LCD/ TV HDMI, dan software aplikasi computer. Adapun software yang digunakan yaitu Microsoft PowerPoint. Bahan-bahan yang digunakan dalam pelatihan seperti kertas, tinta printer, kain spanduk, dan sebagainya yang merupakan kebutuhan alat tulis menulis yang digunakan peserta dan pemateri/ instruktur kegiatan pelatihan.

Penyajian materi terdiri atas materi pengantar berupa materi tentang pentingnya teknologi dalam mengoptimalkan pembelajaran dan pentingnya latihan soal untuk menambah pengetahuan dan keterampilan siswa, serta materi cara pembuatan soal interaktif yang disertai dengan praktikum cara pembuatan soal interaktif

Peserta pelatihan adalah mahasiswa masyarakat calon guru atau lulusan sarjana program pendidikan matematika yang belum mendapatkan pekerjaan tetap sebagai guru. Beberapa persyaratan bagi peserta pelatihan sebagai berikut: (1) masyarakat calon guru atau lulusan sarjana pendidikan khususnya lulusan sarjana pada Jurusan Matematika FMIPA UNM; (2) masyarakat umum lainnya yang membutuhkan kompetensi sesuai dengan tema pelatihan; (3) masyarakat pengajar guru untuk pendidikan formal dan pendidikan nonformal; dan (4) peserta diwajibkan mengikuti seluruh kegiatan pelatihan.

Khalayak sasaran utama dalam kegiatan ini yaitu masyarakat calon guru atau lulusan program sarjana pendidikan yang belum mendapatkan pekerjaan tetap sebagai tenaga pengajar guru. Dengan kegiatan ini diharapkan dapat meningkatkan kemampuan dalam membuat media pembelajaran dan mengembangkan software-software yang terkait dengan media pembelajaran.

Dalam kegiatan penerapan IbM digunakan bahan-bahan materi pelatihan yang meliputi: (1) media pembelajaran; (2) pentingnya dan kegunaan media pembelajaran; (3) media pembelajaran matematika atau alat peraga matematika; (4) jenis-jenis media pembelajaran 
matematika; (5) praktek pembuatan media pembelajaran matematika; (6) pengembangan software-software media pembelajaran matematika; dan (7) konsultasi pengembangan media pembelajaran.

Bahan dan peralatan yang digunakan untuk mendukung pelaksanaan kegiatan ini yaitu alat-alat pertukangan, bahan kerja ATK, dan alat-alat IT. Software-software digunakan sebagai alat utama untuk melakukan pengembangan software.

Target luaran kegiatan mengacu pada tujuan dan manfaat yang diharapkan yaitu meningkatkan kemampuan dan keterampilan masyarakat calon guru untuk membuat media pembelajaran dan mengembangkan perangkat lunak atau software-software komputer mediamedia pembelajaran matematika. Manfaat kegiatan yang diharapkan yaitu masyarakat calon guru mampu membuat media-media pembelajaran, sehingga media pembelajaran tersebut dapat digunakan dalam proses pembelajaran pada pendidikan formal dan pendidikan nonformal. Selain hal tersebut, juga diharapkan dapat meningkatkan kompetensi atau keterampilan dalam mengembangkan software-software media pembelajaran matematika atau alat peraga matematika yang dapat membangun suatu unit usaha/bisnis yang memiliki prospek dan nilai ekonomis yang tinggi. Dari segi ekonomi, kegiatan ini akan sangat membantu khalayak sasaran masyarakat calon guru yaitu dengan melakukan pembuatan media pembelajaran dapat menghasilkan produk yang memiliki nilai jual tinggi.

Dalam kegiatan IbM pelatihan ini dibutuhkan kepakaran dan sumber daya manusia yang mendukung, seperti untuk pemateri atau instruktur (1) Drs. Bahar, M.Si. pakar dalam pengembangan media pembelajaran matematika, (2) Drs. H. Bernard, M.S. pakar dan tenaga ahli dalam pengembangan pendidikan, (3) Dr. Ilham Minggi, M.Si. pakar dan tenaga ahli dalam pengembangan media pembelajaran dan pakar pengembangan pendidikan, dan (4) Ahmad Zaki, S.Si., M.Si. dengan keahlian dalam bidang pengembangan media pembelajaran matematika dan pengembangan software.

metode pendekatan yang digunakan dalam kegiatan ini diuraikan sebagai berikut:

1. Sosialisasi pentingnya mengoptimalkan pembelajaran dengan bantuan teknologi

2. Penjelasan materi pentingnya latihan soal

3. Pelatihan pembuatan soal interaktif.

Praktek pembuatan soal interaktif sesuai dengan pembagian kelompok dan materi yang diperoleh.

\section{HASIL DAN PEMBAHASAN}

Persiapan pelaksanaan kegiatan penerapan IbM sudah dimulai sebelum pelaksanaan pelatihan, dimulai dari (1) perekrutan peserta, (2) persiapan materi/bahan pembelajaran, (3) penyusunan jadwal, (4) konfirmasi narasumber, (5) persiapan administrasi kegiatan, (6) konfirmasi kesiapan dan penggunaan workshop/bengkel kerja dan laboratorium komputer, dan sebagainya.

Pembukaan kegiatan penerapan IbM mengenai Pembuatan Media Pembelajaran Matematika dan Pengembangan Software Media Pembelajaran bagi Masyarakat Calon Guru untuk Pendidikan Formal dan Pendidikan Nonformal dilaksanakan pada hari Sabtu tanggal 20 Juni 2015 diruang laboratorium komputer Jurusan Matematika FMIPA UNM.

Kegiatan pelatihan dalam penerapan IbM dilaksanakan pada hari Sabtu dan Minggu tanggal 20-21 Juni, 27-28 Juni, dan selanjutnya dilakukan kerja mandiri berupa praktek pembuatan media pembelajaran matematika, pengembangan software media pembelajaran dan bimbingan konsultasi terhadap praktek kerja yang dilakukan oleh peserta. 
JURNAL SAINTIFIK VOL.3 NO.1, JANUARI 2017

Dalam pelaksanaan penerapan IbM, beberapa kelebihan diantaranya jenis pelatihan dalam penerapan $\mathrm{IbM}$ sangat khusus meningkatkan kemampuan dan keterampilan peserta membuat media pembelajaran dan mengembangkan software media pembelajaran. Mungkin jenis pelatihan lainnya dalam kegiatan penerapan IbM belum ada yang seperti ini. Selain hal tersebut kelebihan lainnya dari segi hasil atau dampak penerapan IbM, dimana hasil yang diperoleh meningkatnya kemampuan dan keterampilan peserta sehingga dapat membuat media pembelajaran matematika dan mengembangkan softwarenya, kemudian selanjutnya hasil penerapan IbM dapat digunakan untuk pelaksanaan proses belajar mengajar matematika pada pendidikan formal dan pendidikan nonformal. Kelemahan dalam penerapan IbM yaitu masih sedikitnya peserta yang dapat mengikuti kegiatan penerapan IbM.

Dari segi motivasi peserta sangat antusias dalam mengikuti kegiatan penerapan IbM yang tampak dalam kehadiran peserta dan kemampuan peserta menyimak materi pelatihan dan melakukan kerja praktek yang cukup tinggi. Pemahaman peserta juga cukup tinggi yang tampak setelah mengikuti materi dan menerapkannya dalam kerja praktek dapat diterima dengan baik oleh peserta. Keterampilan peserta juga sudah cukup memadai, dimana para peserta mampu mengoperasikan software-software dengan baik. Hal tersebut disebabkan oleh peserta yang berasal dari mahasiswa tingkat akhir jurusan Matematika FMIPA UNM.

Alat dan bahan yang digunakan dalam penerapan IbM cukup memadai, misalnya peralatan dan bahan-bahan penunjang yang tersedia pada bengkel/workshop matematika dan fasilitas laptop/komputer, jaringan koneksi internet, software-software pendukung, dan sebagainya sudah tersedia dengan baik di Laboratorium Komputer Jurusan Matematika FMIPA UNM. Dalam hal dukungan terhadap pelaksanaan penerapan IbM, pihak pimpinan jurusan Matematika dan fakultas MIPA sangat mendukung dan memberi support yang baik untuk pelaksanaan penerapan IbM.

Evaluasi yang digunakan untuk mengetahui peningkatan pengetahuan dan keterampilan peserta dalam penerapan IbM yaitu dengan memberi tugas kerja mandiri kepada peserta melakukan pembuatan media pembelajaran matematika dan mengembangkan softwarenya. Selama proses kerja mandiri tersebut, peserta senantiasa berkonsultasi kepada para narasumber jika ada masalah dan hal-hal yang belum diketahui mengenai pembuatan media pembelajaran dan pengembangan softwarenya. Hasil yang diperoleh dari kerja mandiri tersebut, peserta sudah dapat menyelesaikan kerja praktek dengan baik.

Penyajian materi dalam kegiatan IbM pelatihan ini terdiri atas dua bagian, yaitu penyajian materi tatap muka atau teori dan kerja praktikum pembuatan media pembelajaran di workshop/bengkel dan kerja praktikum pengembangan software di laboratorium komputer.

Adapun penyajian materi tatap muka (teori) meliputi:

a. Pembuatan media pembelajaran matematika Bintang Plus Minus;

b. Pembuatan media pembelajaran matematika Monopoli Matematika;

c. Pembuatan media pembelajaran matematika Permainan Sepakbola Matematika;

d. Pengembangan Software media pembelajaran matematika.

Adapun penyajian materi kerja paraktikum meliputi:

a. Praktek pembuatan media pembelajaran Bintang Plus Minus;

b. Praktek pembuatan media pembelajaran Monopoli Matematika;

c. Praktek pembuatan media pembelajaran Permainan Sepakbola Matematika;

d. Pengembangan software media pembelajaran.

Metode yang digunakan dalam penyajian materi yaitu metode ceramah oleh pemateri/instruktur dan diskusi tanya jawab antara pemateri dengan peserta kegiatan. 
Jumlah peserta yang mengikuti kegiatan penerapan IbM ini sebanyak 25 orang yang terdiri atas masyarakat calon guru yaitu mahasiswa yang sudah tingkat akhir dalam penyelesaian studinya yang dapat menggunakan hasil penerapan IbM berupa media pembelajaran matematika untuk proses belajar mengajar pada pendidikan formal dan pendidikan nonformal.

Pemateri/instruktur dalam kegiatan penerapan IbM ini terdiri atas tim pelaksana $\mathrm{IbM}$ yang beranggotakan 4 orang. Pemateri/instruktur tersebut yaitu Dr. Ilham Minggi, M.Si., Drs. H. Bernard, M.S., Drs. Bahar, M.Si., dan Ahmad Zaki, S.Si., M.Si. Selain anggota tim pelaksana IbM tersebut, dalam pelaksanaan IbM juga didukung oleh supporting staf yang terdiri atas asistenasisten bengkel/workshop kerja dan laboratorium komputer.

Beberapa langkah-langkah kerja kegiatan praktikum sebagai berikut:

a. Menyiapkan bahan/materi praktikum

b. Menyiapkan alat dan bahan praktikum, seperti kesiapan bengkel/workshop kerja, bahan dan alat dalam bengkel, komputer/laptop, LCD projektor, dan sudah tersedianya instal/program pada laptop yang akan digunakan.

c. Melaksanakan praktikum pembuatan media dan pengembangan software.

d. Membimbing para peserta untuk melakukan tahapan-tahapan atau langkah-langkah pembuatan media dan pengembangan software.

e. Melakukan diskusi dengan peserta mengenai cara melakukan pembuatan media dan pengembangan software.

f. Memberikan contoh pengembangan software kepada peserta.

g. Memberikan masalah/tugas kepada peserta.

Software-software digunakan sebagai alat utama untuk melakukan pengembangan software. Adapun software-software yang digunakan sebagai berikut:

\section{a. Visual Basic}

Microsoft Visual Basic (sering disingkat sebagai VB saja) merupakan sebuah bahasa pemrograman yang menawarkan Integrated Development Environment (IDE) visual untuk membuat program perangkat lunak berbasis sistem operasi Microsoft Windows dengan menggunakan model pemrograman (COM).

Visual Basic merupakan turunan bahasa pemrograman BASIC dan menawarkan pengembangan perangkat lunak komputer berbasis grafik dengan cepat.

Beberapa bahasa skrip seperti Visual Basic for Applications (VBA) dan Visual Basic Scripting Edition (VBScript), mirip seperti halnya Visual Basic, tetapi cara kerjanya yang berbeda.

Para programmer dapat membangun aplikasi dengan menggunakan komponenkomponen yang disediakan oleh Microsoft Visual Basic Program-program yang ditulis dengan Visual Basic juga dapat menggunakan Windows API, tapi membutuhkan deklarasi fungsi luar tambahan.

Dalam pemrograman untuk bisnis, Visual Basic memiliki pangsa pasar yang sangat luas. Sebuah survey yang dilakukan pada tahun 2005 menunjukkan bahwa $62 \%$ pengembang perangkat lunak dilaporkan menggunakan berbagai bentuk Visual Basic, yang diikuti oleh $\mathrm{C}++$, JavaScript, C\#, dan Java.

b. Matlab

MATLAB (matrix laboratory) adalah sebuah lingkungan komputasi numerikal dan bahasa pemrograman komputer generasi keempat. Dikembangkan oleh The MathWorks, MATLAB memungkinkan manipulasi matriks, pem-plot-an fungsi dan data, implementasi algoritma, pembuatan antarmuka pengguna, dan peng-antarmuka-an dengan program dalam 
JURNAL SAINTIFIK VOL.3 NO.1, JANUARI 2017

bahasa lainnya. Meskipun hanya bernuansa numerik, sebuah kotak kakas (toolbox) yang menggunakan mesin simbolik MuPAD, memungkinkan akses terhadap kemampuan aljabar komputer. Sebuah paket tambahan, Simulink, menambahkan simulasi grafis multiranah dan Desain Berdasar-Model untuk sistem terlekat dan dinamik.

Pada tahun 2004, MathWorks mengklaim bahwa MATLAB telah dimanfaatkan oleh lebih dari satu juta pengguna di dunia pendidikan dan industri.

\section{c. Maple}

Maple adalah komersial sistem aljabar komputer yang dikembangkan dan dijual secara komersial oleh Maplesoft, sebuah perusahaan perangkat lunak yang berbasis di Waterloo, Ontario, Kanada. Versi utama saat ini adalah versi 2015, yang dirilis pada bulan Maret 2015.

Ini pertama kali dikembangkan pada tahun 1980 oleh Simbolik Komputasi Grup di University of Waterloo. Pada tahun 1988, Maplesoft (kemudian dikenal sebagai Waterloo Maple Inc.) didirikan untuk mengkomersilkan teknologi.

Pengguna dapat memasukkan matematika di tradisional notasi matematika. Antarmuka kustom pengguna juga dapat dibuat. Ada dukungan untuk perhitungan numerik, untuk presisi sewenang-wenang, serta perhitungan simbolik dan visualisasi. Contoh perhitungan simbolik diberikan di bawah ini.

Maple menggabungkan dinamis mengetik penting gaya bahasa pemrograman yang menyerupai Pascal. Bahasa memungkinkan variabel leksikal lingkup. Ada juga antarmuka untuk bahasa lain (C, C \#, Fortran, Java, MATLAB, dan Visual Basic). Ada juga sebuah antarmuka dengan Excel.

Maple mendukung MathML 2.0, format W3C untuk mewakili dan menafsirkan ekspresi matematika, termasuk tampilan mereka di halaman Web.

\section{d. Microsoft PowerPoint}

Microsoft PowerPoint atau Microsoft Office PowerPoint atau PowerPoint adalah sebuah program komputer untuk presentasi yang dikembangkan oleh Microsoft di dalam paket aplikasi kantoran mereka, Microsoft Office, selain Microsoft Word, Excel, Access dan beberapa program lainnya. PowerPoint berjalan di atas komputer PC berbasis sistem operasi Microsoft Windows dan juga Apple Macintosh yang menggunakan sistem operasi Apple Mac OS, meskipun pada awalnya aplikasi ini berjalan di atas sistem operasi Xenix. Aplikasi ini sangat banyak digunakan, apalagi oleh kalangan perkantoran dan pebisnis, para pendidik, siswa, dan trainer. Dimulai pada versi Microsoft Office System 2003, Microsoft mengganti nama dari sebelumnya Microsoft PowerPoint saja menjadi Microsoft Office PowerPoint. Lalu, pada Office 2013, namanya cukup disingkat PowerPoint. Versi terbaru dari PowerPoint adalah versi 15 (Microsoft Office PowerPoint 2013), yang tergabung ke dalam paket Microsoft Office 2013. Software ini juga digunakan dalam pengembangan software media pembelajaran matematika.

Dalam pelaksanaan penerapan IbM, beberapa kelebihan diantaranya jenis pelatihan dalam penerapan IbM sangat khusus meningkatkan kemampuan dan keterampilan peserta membuat media pembelajaran dan mengembangkan software media pembelajaran. Mungkin jenis pelatihan lainnya dalam kegiatan penerapan IbM belum ada yang seperti ini. Selain hal tersebut kelebihan lainnya dari segi hasil atau dampak penerapan $\mathrm{IbM}$, dimana hasil yang diperoleh meningkatnya kemampuan dan keterampilan peserta sehingga dapat membuat media pembelajaran matematika dan mengembangkan softwarenya, kemudian selanjutnya hasil penerapan IbM dapat digunakan untuk pelaksanaan proses belajar mengajar matematika pada pendidikan formal dan pendidikan nonformal. Kelemahan dalam penerapan IbM yaitu masih sedikitnya peserta yang dapat mengikuti kegiatan penerapan IbM. 
Dari segi motivasi peserta sangat antusias dalam mengikuti kegiatan penerapan IbM yang tampak dalam kehadiran peserta dan kemampuan peserta menyimak materi pelatihan dan melakukan kerja praktek yang cukup tinggi. Pemahaman peserta juga cukup tinggi yang tampak setelah mengikuti materi dan menerapkannya dalam kerja praktek dapat diterima dengan baik oleh peserta. Keterampilan peserta juga sudah cukup memadai, dimana para peserta mampu mengoperasikan software-software dengan baik. Hal tersebut disebabkan oleh peserta yang berasal dari mahasiswa tingkat akhir jurusan Matematika FMIPA UNM.

Alat dan bahan yang digunakan dalam penerapan IbM cukup memadai, misalnya peralatan dan bahan-bahan penunjang yang tersedia pada bengkel/workshop matematika dan fasilitas laptop/komputer, jaringan koneksi internet, software-software pendukung, dan sebagainya sudah tersedia dengan baik di Laboratorium Komputer Jurusan Matematika FMIPA UNM. Dalam hal dukungan terhadap pelaksanaan penerapan IbM, pihak pimpinan jurusan Matematika dan fakultas MIPA sangat mendukung dan memberi support yang baik untuk pelaksanaan penerapan IbM.

Evaluasi yang digunakan untuk mengetahui peningkatan pengetahuan dan keterampilan peserta dalam penerapan IbM yaitu dengan memberi tugas kerja mandiri kepada peserta melakukan pembuatan media pembelajaran matematika dan mengembangkan softwarenya. Selama proses kerja mandiri tersebut, peserta senantiasa berkonsultasi kepada para narasumber jika ada masalah dan hal-hal yang belum diketahui mengenai pembuatan media pembelajaran dan pengembangan softwarenya. Hasil yang diperoleh dari kerja mandiri tersebut, peserta sudah dapat menyelesaikan kerja praktek dengan baik.

\section{KESIMPULAN DAN SARAN}

\section{Kesimpulan}

Kesimpulan dalam kegiatan ini sebagai berikut: (1) dengan pelaksanaan IbM dapat meningkatkan kemampuan dan keterampilan masyarakat calon guru untuk membuat media pembelajaran dan (2) meningkatnya kemampuan masyarakat calon guru dalam mengembangkan perangkat lunak atau software-software komputer media-media pembelajaran matematika atau alat peraga matematika.

Saran

Saran dari pelaksanaan kegiatan sebagai berikut: (1) perlunya kegiatan penerapan IbM seperti ini dengan cakupan yang lebih luas peserta kegiatan penerapan IbM berasal dari mahasiswa dan masyarakat lainnya dan (2) menurut hasil dan manfaat yang diperoleh dari kegiatan penerapan IbM, perlu dilakukan lagi penerapan IbM bagi mahasiswa tingkat akhir untuk mendukung proses pelaksanaan pembelajaran pada pendidikan formal dan nonformal.

\section{DAFTAR PUSTAKA}

Download, website: http://id.wikipedia.org/wiki/Pelatihan. Diakses Senin 21 Maret 2011 pukul 15.23 .

Franco, EA. (1991). Training, Quizon City: kalayan Press Mktg Ent Inc.

Gibson. (1997). Organisasi, Perilaku, Struktur, Proses. Alih Bahasa Nunuk Ardiani. Jakarta : Binarupa Aksara

Marzuki, M.S, (1992). Strategi dan Model Pelatihan, Malang: IKIP Malang. 


\section{JURNAL SAINTIFIK VOL.3 NO.1, JANUARI 2017}

Moekijat, 1990. Evaluasi Pelatihan dalam Rangka Meningkatkan Produktivitas Perusahaan, Bandung, Penerbit Mandar Maju.

Moekijat, (1990). Pengembangan dan Motivasi, Bandung: Pionir Jaya.

Nawawi, H, (1997). Manajemen Sumber Daya Manusia, Yogyakarta, Gajah Mada Universitas Press.

Simamora, H, (1997). Manajemen Sumber Daya Manusia, Yogyakarta, Bagian Penerbitan STIE

Sukmalana, S. (2003). Kinerja Dosen Perguruan Tinggi Swasta, Analisa Pengaruh Tingkat Pendidikan, Motivasi Berprestasi, dan Kultur Organisasi terhadap Kinerja Dosen dalam Tridarma Perguruan Tinggi di Tiga Perguruan Tinggi Swasta Jawa Barat, Disertasi, PPS UPI.

Tjiptono, F dan Diana, A, (1998). Total Quality' Management, Yogyakarta : Andi offset.

Veithzal Rivai,. (2004). Manajemen Sumber Daya Manusia Untuk Perusahaan, Jakarta, PT. Raja Grafindo Persada 